\title{
Evaluation of the importance of acclimation of needle structure, photosynthesis, and respiration to available photosynthetically active radiation in a Scots pine canopy
}

\author{
S. Palmroth and P. Hari
}

\begin{abstract}
We analyzed the combined effect of differences in the photosynthetic light response curve and in the distributions of photosynthetically active radiation (PAR) irradiance within the canopy on the $\mathrm{CO}_{2}$ exchange rates of Scots pine (Pinus sylvestris L.) shoots. Nitrogen concentration did not vary with depth within the canopy, but leaf mass per area (LMA) ranged from 58.2 to $95.2 \mathrm{~g} \cdot \mathrm{m}^{-2}$ (all needle age-classes pooled) and increased with increasing available PAR. The photosynthetic light response curves of 75 randomly sampled, 1-year-old shoots (with a fixed structure) were measured in the laboratory. No statistically significant differences in photosynthetic parameters or stomatal conductance either on an area or mass basis were detected between the top, middle, and bottom zones of the canopy. However, a significant decrease occurred in the area-based dark respiration rate $\left(R_{\mathrm{d}}\right)$ with increasing depth in the canopy. The areabased maximum $\mathrm{CO}_{2}$ exchange rate was weakly correlated with needle nitrogen content $\left(N_{\text {area }}\right)$ and LMA, whereas $R_{\mathrm{d}}$ showed a higher correlation with both $N_{\text {area }}$ and LMA. Estimates of the $\mathrm{CO}_{2}$ exchange rate over a day (24 h) in July suggest that the apparently small differences in mean light response curves of the canopy zones are reflected in the enhanced performance of shade needles in low light conditions because of reduced respiration costs. Based on our results, structural acclimation of needles along the light gradient, rather than changes in biochemical machinery, appears to be the more important acclimation process in Scots pine.
\end{abstract}

Résumé : Nous avons analysé l'effet combiné des différences dans la courbe de réponse à la lumière de la photosynthèse et dans la distribution de l'irradiance du rayonnement photosynthétiquement actif (RPA) au travers du couvert sur le taux d'échange de $\mathrm{CO}_{2}$ de pousses de pin sylvestre (Pinus sylvestris L.). La concentration en azote ne dépendait pas de la profondeur dans le couvert, mais la masse foliaire spécifique variait de 58,2 à $95,2 \mathrm{~g} \cdot \mathrm{m}^{-2}$ (toutes les classes d'âge des aiguilles confondues) et augmentait avec une augmentation du RPA disponible. Les courbes de réponse à la lumière de la photosynthèse de 75 pousses (de structure déterminée) âgées d'un an et choisies aléatoirement ont été mesurées au laboratoire. Aucune différence statistiquement significative n'a été détectée entre les zones du haut, du milieu ou du bas du couvert pour les paramètres de la photosynthèse ou de la conductance stomatique, exprimés en fonction de la surface ou de la masse. Toutefois, une baisse importante de la respiration à la noirceur exprimée en fonction de la surface $\left(R_{\mathrm{d}}\right)$ est apparue avec la profondeur dans le couvert. Le taux d'échange maximal de $\mathrm{CO}_{2}$, exprimé en fonction de la surface, était faiblement corrélé avec le contenu en azote des aiguilles $\left(N_{\text {area }}\right)$ et la masse foliaire spécifique, alors que $R_{\mathrm{d}}$ montrait une corrélation plus forte à la fois avec $N_{\text {area }}$ et la masse foliaire spécifique. Les estimations du taux d'échange de $\mathrm{CO}_{2}$ pendant une journée $(24 \mathrm{~h})$ au cours du mois de juillet suggèrent des différences en apparence faibles dans les courbes moyennes de réponse à la lumière entre les zones du couvert. Ces différences sont reflétées dans la performance améliorée des aiguilles d'ombre dans des conditions de faible luminosité grâce aux coûts respiratoires réduits. Sur la base de nos résultats, l'acclimatation structurelle des aiguilles le long du gradient de lumière, plutôt que des changements dans la machinerie biochimique, semble être le processus d'acclimatation le plus important chez le pin sylvestre.

[Traduit par la Rédaction]

\section{Introduction}

Efficiency of energy conversion from photosynthetically active radiation (PAR) into carbohydrates depends on the balance between the availability of resources (light, water, nutrients) at the leaf level. In the absence of other stresses, $\mathrm{CO}_{2}$ fixation of the canopy is determined by the gradients of PAR and the acclimation of the leaf structure and functioning along these gradients. Abundant evidence exists that sun leaves in tree stands have a greater photosynthetic capacity

Received June 12, 2000. Accepted February 25, 2001. Published on the NRC Research Press Web site at http://cjfr.nrc.ca on June 26, 2001.

S. Palmroth. ${ }^{1}$ Department of Limnology and Environmental Protection, P.O. Box 62, University of Helsinki 00014, Finland.

P. Hari. Department of Forest Ecology, P.O. Box 27, University of Helsinki 00014, Finland.

${ }^{1}$ Corresponding author (e-mail: sari.palmroth@helsinki.fi). 
than their shade-acclimated counterparts (Kull and Koppel 1987; Ellsworth and Reich 1993; Harley and Baldocchi 1995; Dang et al. 1997; Kull and Niinemets 1998; Bond et al. 1999). Shade leaves, in turn, are likely to have lower dark respiration rates and light compensation points than sun leaves (Brooks et al. 1991; Ellsworth and Reich 1993). The structure of leaves, e.g., leaf mass per area (LMA) increases with increasing availability of PAR during growth (Kellomäki and Oker-Blom 1981; Kull and Koppel 1987; van Hees and Bartelink 1993; Niinemets and Kull 1995; Stenberg et al. 1999).

While strong correlation between foliage structure (foliar $\mathrm{N}$, LMA), photosynthetic properties, and the PAR regime is expected, recent studies indicate that these relationships may vary among tree species and with varying shade tolerance (Dang et al. 1997; Kull and Niinemets 1998; Bond et al. 1999). In addition, factors, such as leaf age and seasonal changes in physiological characteristics (Reich et al. 1991; Vapaavuori et al. 1995; Schoettle and Smith 1999) can affect these relationships, which also depend on the proportion of $\mathrm{N}$ that is used in processes not directly related to photosynthesis (Niinemets and Tenhunen 1997). Moreover, other environmental factors and the position within a crown may influence leaf-level gas exchange (Kull and Koppel 1987; Irvine et al. 1998).

Scots pine (Pinus sylvestris L.) is a shade-intolerant species, and its acclimative responses to shading remain obscure. In pine canopies, the photosynthesizing needle area is grouped into shoots and crowns, and narrow needles give rise to penumbral radiation. Both of these factors are likely to decrease the steepness of the light gradient. Changes in needle structure along the light gradient are accompanied by changes in shoot structure (Niinemets and Kull 1995; Leverenz 1996; Sprugel et al. 1996; Stenberg et al. 1999, 2001). This complicates the separation between structural and physiological acclimation to shade. Furthermore, while changes in foliage structure are likely to influence the photosynthetic properties of the needles, they also alter the distributions of PAR within the canopy (Stenberg 1998). Instrumentation providing high resolution empirical data on spatial distribution of direct sunlight within a coniferous canopy has only recently been available. Consequently, there is a scarcity of measured data on PAR irradiance, where the large spatial and temporal variation can be adequately estimated (Palva et al. 1998; Vesala et al. 2000). Measurements and model simulations producing data of this level of precision are needed for realistic estimation of photosynthetic rates within a canopy.

Comparison of parameters of photosynthetic light response curves gives information on differences in, for instance, photosynthetic capacity of foliage grown under various light conditions. However, the ecological significance of these differences can be evaluated by looking at photosynthetic performance in the "original" growing conditions and over time periods long enough to include the effect of nighttime respiration on carbon balance (Korpilahti and Hari 1978; Givnish 1988). Integrating the photosynthetic light response over a distribution of PAR irradiance (including spatial and temporal variation) takes into account the proportions of time spent at different points along the nonlinear response curve. The proportion of PAR irradiance re- ceived at or above the saturating levels or close to the light compensation point is likely change with depth in the canopy.

We chose to sample 1-year-old Scots pine shoots to investigate differences in photosynthetic light response curves along the naturally occurring vertical light gradient within the canopy. Representative sample of the studied population was obtained by random sampling. Since we wanted to study the possible differences in $\mathrm{CO}_{2}$-exchange properties of needles, the shoot structure was standardized. We measured and calculated shoot-level $\mathrm{CO}_{2}$ exchange rates for shoots with a fixed structure, i.e., the effect of shoot structure on the performance was assumed to be constant. The gradient in the available light was quantified by measuring distributions of PAR irradiance on horizontal plains at different depths in the canopy (see Vesala et al. 2000).

Our objective was to evaluate the combined effect of the differences in photosynthetic light response curves and the distributions of PAR irradiance on the $\mathrm{CO}_{2}$ exchange of shoots with a fixed structure. More specifically, we aimed (i) to analyze the acclimation of the photosynthetic light response along the PAR gradient and (ii) to evaluate the importance of the changes in the shape of response curves on $\mathrm{CO}_{2}$ exchange, integrated over a daily PAR irradiance distribution at different depths in the canopy.

\section{Materials and methods}

\section{$\mathrm{CO}_{2}$-exchange model}

The model used in this study is based on the ideas of optimal behaviour of stomata, originally introduced by Cowan (1977). In the present formulation, a linear relationship is assumed between the substomatal $\mathrm{CO}_{2}$ concentration $\left(C_{\mathrm{i}}\right)$ and photosynthesis (Hari et al. 1986). This model has been previously used to predict daily patterns in photosynthesis and transpiration of Scots pine (Berninger and Hari 1993; Berninger et al. 1996; Hari et al. 1999, 2000) and to estimate instantaneous water-use efficiencies (Palmroth et al. 1999). As documented in Mäkelä et al. (1996), the model describes the rates of photosynthesis $(A)$, transpiration $(E)$, and stomatal conductance $\left(g_{\mathrm{s}}\right)$ of a needle area element, when $0<g_{\mathrm{s}}<g_{\max }$, as

$$
\begin{aligned}
& A_{\mathrm{n}}=A+R_{\mathrm{d}} \\
& A=f(I) C_{\mathrm{i}}=\frac{g_{\mathrm{s}} C_{\mathrm{a}} f(I)}{g_{\mathrm{s}}+f(I)}
\end{aligned}
$$

where the function $f(I)$ is described by

$$
f(I)=\frac{\alpha I}{I+\gamma}
$$

$$
\begin{aligned}
E & =1.6 g_{\mathrm{s}} D \\
g_{\mathrm{s}} & =\left(\sqrt{\frac{\lambda C_{\mathrm{a}}}{1.6 D}-1}\right) \frac{A}{C_{\mathrm{i}}}
\end{aligned}
$$

where $A_{\mathrm{n}}\left(\mu \mathrm{mol} \cdot \mathrm{m}^{-2} \cdot \mathrm{s}^{-1}\right)$ is $\mathrm{CO}_{2}$ exchange rate; $R_{\mathrm{d}}\left(\mu \mathrm{mol} \cdot \mathrm{m}^{-2} \cdot \mathrm{s}^{-1}\right)$ is dark respiration rate; $g_{\mathrm{s}}\left(\mathrm{mol} \cdot \mathrm{m}^{-2} \cdot \mathrm{s}^{-1}\right)$ is stomatal conductance for $\mathrm{CO}_{2} ; C_{\mathrm{a}}$ and $C_{\mathrm{i}}$ are ambient and intercellular $\mathrm{CO}_{2}$ mole fractions, respectively; $I\left(\mu \mathrm{mol} \cdot \mathrm{m}^{-2} \cdot \mathrm{s}^{-1}\right)$ is PAR irradiance; $\alpha\left(\mathrm{mol} \cdot \mathrm{m}^{-2} \cdot \mathrm{s}^{-1}\right)$ is carboxylation efficiency; $\gamma\left(\mu \mathrm{mol} \cdot \mathrm{m}^{-2} \cdot \mathrm{s}^{-1}\right)$ is a light saturation parameter; $E\left(\mathrm{~mol} \cdot \mathrm{m}^{-2} \cdot \mathrm{s}^{-1}\right)$ is transpiration rate; $D$ is the leaf-to-air water vapor mole fraction difference; 1.6 is a constant converting $g_{\mathrm{s}}$ for $\mathrm{CO}_{2}$ to that of water vapor; and $\lambda\left((\mathrm{mol} \mathrm{H} \mathrm{H}) \cdot\left(\mathrm{mol} \mathrm{CO}_{2}\right)^{-1}\right)$ 
is a parameter describing the intrinsic water-use efficiency (the higher the value of $\lambda$ the lower is the water-use efficiency).

\section{Gas-exchange measurements}

The measurements were performed at Hyytiälä forest field station in southern Finland $\left(61^{\circ} 51^{\prime} \mathrm{N}, 24^{\circ} 17^{\prime} \mathrm{E}\right)$. Characteristics of $34-$ year-old Scots pine stand were determined from a sample plot of 46 trees. A stratified sampling procedure was used in the selection of shoots for gas-exchange measurements. The trees were divided into three size classes (according to height) and the canopy into three zones (I, 11.0-13.0 m; II, 9.5-11.0 m; III, 8.0-9.5 m). The number of sampled trees from each size class was proportional to the number of trees in the class. Gas exchange measurements were performed during three periods in summer 1997 (May 29 - June 10; July 2-10; August 12-20). To evaluate the within-tree variation, six or seven shoots from three trees were measured in June. In July and August, 27 and 29 shoots, respectively, from different size classes and canopy zones were sampled randomly. Altogether, gasexchange measurements from 75 (27, 27, and 21 from zones I-III, respectively) shoots were analyzed.

Gas exchange was measured using an open laboratory system (see Koskela et al. 1999) with air flowing continuously through a black-walled, thermostated chamber. Water vapor and $\mathrm{CO}_{2}$ were removed from incoming air by columns of silica gel and soda lime. Total air flow through the system and injection of $\mathrm{CO}_{2}$-rich gas $\left(20 \% \mathrm{CO}_{2}\right.$ and $80 \% \mathrm{~N}_{2}$ ) were regulated by mass flow controllers (5850TR, Brooks Instrument B.V., Netherlands). Water vapor and $\mathrm{CO}_{2}$ concentrations were measured with two infrared gas analyzers (URAS 3G, Hartmann \& Braun AG, Germany) and $\mathrm{CO}_{2}$ also with a differential infrared gas analyzer (URAS $3 \mathrm{G}$ ). Irradiance was supplied by a manually regulated daylight lamp (Metallogen HMI, 1200 W/GS, OSRAM GmbH, Germany) and was measured with a PAR sensor (Delta-T Devices, Cambridge, U.K.). Temperature was measured with two copper-constantan thermocouples and controlled by a computer connected to a control unit (Lauda R22 MGW, Lauda, Köningshofen, Germany) equipped with a temperature controller (Lauda RC6 MGW).

The $\mathrm{CO}_{2}$ and $\mathrm{H}_{2} \mathrm{O}$ exchange rates were measured of detached shoots that were recut under water and then brought to the laboratory. Results from previous comparison of gas-exchange rates before and after twig excision in Scots pine and other conifers have shown no dramatic changes occurring within hours postexcision (see Beadle et al. 1985; Bergh 1997; Schoettle and Smith 1999). Parts of shoots with 1-year-old needles $(\approx 2 \mathrm{~cm}$ of the twig) were used in the measurements, and the number of fascicles was reduced to 20-30 to diminish the mutual shading of the needles. The shoot was illuminated "from the top," such that shoot axis was parallel to the direction of view (light beam) (see Fig. 4). Gas exchange was measured at 11 different PAR irradiance levels from 2000 to $0 \mu \mathrm{mol} \cdot \mathrm{m}^{-2} \cdot \mathrm{s}^{-1}$. The shoot was allowed to acclimate for 5 min after each level change in irradiance. Carbon dioxide concentration of incoming air was $358 \pm 2 \mathrm{ppm}$, temperature was maintained at $19 \pm 0.5^{\circ} \mathrm{C}$ and the average water vapor mole fraction difference was $13 \pm 2 \mathrm{mmol} \cdot \mathrm{mol}^{-1}$ during the measurements. Gas-exchange rates were calculated both per total needle area and dry mass.

The leaf mass per area (LMA) was determined based on a sample of 10 needles taken from each measured shoot. Needle thickness, width, and length were measured and used for calculation of total needle surface area. Needle shape was assumed to be half ellipse. The needles were then dried $\left(24 \mathrm{~h}\right.$ at $\left.104^{\circ} \mathrm{C}\right)$ and weighed. A subsample of dried needles was homogenized and the total nitrogen concentration analyzed with an automatic CHN-900 analyzer (Leco Co., St. Joseph, Mich.). The shoot silhouette area was determined from photographs (a subsample of 35 shoots) taken from the direction of illumination. Photographs of silhouette areas were analyzed using the software WinNeedle 1.0 (Regent Instruments,
Montréal, Que.) and used for calculating the estimates of shoot silhouette to total needle area ratio (STAR) (Oker-Blom and Smolander 1988).

\section{Parameter estimation}

The parameters of the $\mathrm{CO}_{2}$-exchange model were estimated by fitting the model response curve (obtained by combining eqs. 1, 2 and 3 ) to the measured rates using a nonlinear curve-fitting procedure (SYSTAT statistical software package, SYSTAT Inc., Evanston, Ill.). The $R_{\mathrm{d}}$ was estimated from gas-exchange measurements made with a darkened chamber. Estimates of $g_{\mathrm{s}}$ at saturating PAR, were obtained from transpiration measurements, and the $C_{\mathrm{i}}$, calculated using the conductance approach $\left(C_{\mathrm{i}}=C_{\mathrm{a}}-A / g_{\mathrm{s}}\right)$, was used to calculate the estimates of $\lambda$ using eq. 5. Shoot-level data was pooled within each canopy zone and measurement period.

The $\mathrm{CO}_{2}$-exchange model has been derived for a needle area element (Hari et al. 1986). In our study, curve fitting was performed for shoot-level gas-exchange rates expressed per unit total needle area. However, the variation in the PAR on the needle area, caused by the shoot structure, was standardized as far as possible, and hence, the mutual shading of the shoots was assumed to be the same. The measured response curve represents an average response of the needle area elements in the chamber as a function of incoming or available PAR irradiance. This applies to the estimate of the maximum $\mathrm{CO}_{2}$-exchange rate (i.e., the asymptote of the response curve), whereas the initial slope of the curve has a different interpretation at the shoot and element levels. At shoot level, the slope is less steep because of the extinction of PAR within the shoot (Stenberg et al. 1995). To get an estimate of the quantum yield, $q$ $\left((\mu \mathrm{mol} \mathrm{CO} 2) \cdot \mathrm{m}^{-2} \cdot \mathrm{s}^{-1} /(\mu \mathrm{mol}\right.$ quanta $\left.) \cdot \mathrm{m}^{-2} \cdot \mathrm{s}^{-1}\right)$, we determined the initial slope of the linear part of the response curve using incident PAR multiplied by the value of STAR, i.e., mean irradiance on the needle area, as the driving variable (see Stenberg et al. 1995).

\section{Statistics used}

Analysis of variance (ANOVA; SYSTAT, Inc.) were performed to detect possible differences in the average gas-exchange characteristics between canopy zones. Since the division of the trees into size classes did not decrease within-group variation in any of the characteristics investigated, this stratification was discarded. All correlation coefficients presented were estimated using simple correlation analysis (Pearson's correlation coefficient; SYSTAT, Inc.).

\section{Measurements of needle mass, foliar nitrogen, and irradiance distributions within the canopy}

The needle area distribution in the canopy was determined by using regressions between needle mass and the corresponding cross-sectional wood area. Tree height, diameter at breast height and at crown base, and height of crown base were measured from each tree on the sample plot. We defined the lowest living whorl as being that in which at least half of the branches were alive (Kaipiainen and Hari 1985). In addition, for six trees the height of the whorls, the diameters (inside bark) between whorls, and the diameters (inside bark) of all the branches were measured. From the six trees, five branches per tree were sampled systematically. Needles were then removed from the branches, dried, and weighed, and total $\mathrm{N}$ concentration and LMA were determined from a sample of 20 needles pooled from all age-classes. Regressions of total branch cross-sectional area to stem area, needle mass to branch area, and needle mass to stem area below the living crown were calculated.

The measuring system for PAR irradiance, placed in the middle of the sample plot, consisted of 161 photosensors (see Vesala et al. 2000). The spectral range of sensitivity of the silicon diodes (VBT 9412B, EG\&G Vactec Optoelectronics) is 330-720 nm, with a maximum at $580 \mathrm{~nm}$. The cross-sectional area of each sensor is $1.6 \mathrm{~mm}^{2}$. The sensors were mounted systematically into five booms 
Fig. 1. Vertical needle area distribution $\left(\mathrm{LAI}, \mathrm{m}^{2} \cdot \mathrm{m}^{-2}\right)$ of the experimental stand and minimum and maximum heights $(\mathrm{cm})$ of the sampled shoots.

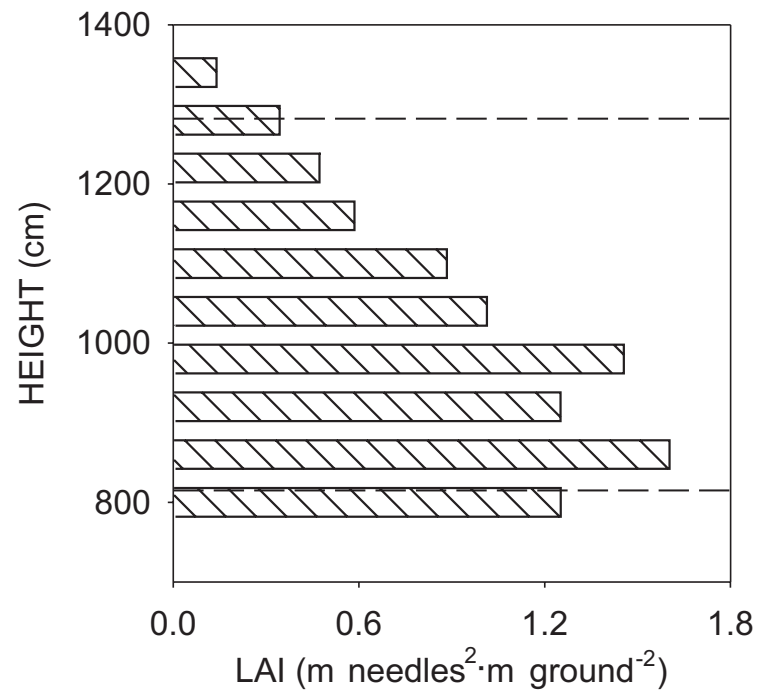

(2-5 m long), which were attached to a pole at different heights $(10.7,10.1,9.5,8.9$, and $8.3 \mathrm{~m})$. Four sensors were placed at a height of $12 \mathrm{~m}$. Data was collected every 7-12 s, on July 16, 1997.

\section{Estimating $\mathrm{CO}_{2}$ exchange over a day}

Estimates of daily $\mathrm{CO}_{2}$ exchange were calculated to evaluate the combined effect of changes in light response function and distribution of PAR irrandiance within the canopy on daily $\mathrm{CO}_{2}$ exchange. The distributions of PAR irradiance measured at heights of 10.7, 9.5, and $8.3 \mathrm{~m}$ (representing the top, middle, and bottom parts of the canopy) were used. The integration time $\left(t_{1}, t_{2}\right)$ was one day $(24 \mathrm{~h})$. No variation was assumed in water vapor deficit, $C_{\mathrm{a}}$, or temperature, and the dark respiration rate was assumed to remain the same in the light. The canopy was assumed to be horizontally homogenous and to consist of shoots having identical structure and orientation. The daily $\mathrm{CO}_{2}$ exchange per unit needle area, $A_{c}$ $\left(\mu \mathrm{mol} \cdot \mathrm{m}^{-2} \cdot \mathrm{day}^{-1}\right)$, for a shoot located at a specific level in the canopy was then calculated using the shoot level response of $\mathrm{CO}_{2^{-}}$ exchange rate to incident PAR, $A_{\mathrm{n}}(I)$, and measured PAR distribution, $f\left(I, t_{1}, t_{2}\right)$ using the following formula:

$$
A_{\mathrm{c}}\left(t_{1}, t_{2}\right)=\int_{0}^{I_{\max }} A_{\mathrm{n}}(I) f\left(I, t_{1}, t_{2}\right) \mathrm{d} I
$$

The $\mathrm{CO}_{2}$ exchange per ground area was estimated using the LAI of a specific layer.

Estimates of $A_{\mathrm{c}}$ were calculated for a "test" day (July 16, 1997), using mean values for the parameters $\alpha, \gamma, g_{\mathrm{s}}$, and $R_{\mathrm{d}}$ determined for foliage from zone I at the level of $10.7 \mathrm{~m}$; using parameter values for zone II at the level of $9.5 \mathrm{~m}$; and using parameter values for zone III at the level of $8.3 \mathrm{~m}$. Similar calculations were made for the three canopy zones but assuming no acclimation, i.e., the performance of an "average" shoot from zone I was simulated (using parameter values from the top) in the light environments of the middle and bottom of the canopy. The same calculations were performed using the sets of parameters determined from gas exchange measurements made in June, July, and August.

\section{Results}

\section{Light regime, distributions of needle area, and foliar nitrogen}

The needle area distribution in the canopy is shown in Fig. 1. The all-sided leaf area index (LAI, defined as the unit needle area per unit ground surface area) was $9.0 \mathrm{~m}^{2} \cdot \mathrm{m}^{-2}$, and the proportions of LAI in canopy zones I-III were 20, 33 , and $47 \%$, respectively. The daily estimates of PAR irradiance $\left(I_{\text {day }}\right)$ integrated over a reasonably clear day (July $16,1997)$ decreased exponentially with cumulative leaf area index $(L)$ (Fig. 2A). The estimate of $I_{\text {day }}$ at the bottom of the living canopy $(8.3 \mathrm{~m})$ was $22 \%$ of the value $46 \mathrm{~mol} \cdot \mathrm{m}^{-2} \cdot$ day $^{-1}$ measured at the top of the canopy $(12 \mathrm{~m})$. The irradiance distributions, measured over the 24-h period at the levels of 10.7 and $8.3 \mathrm{~m}$ (Fig. 2B), showed that, while the peak values received at the lower levels of the canopy were relatively high and comparable with the upper canopy values, a distinctive change occurred in the shape of the distribution.

No variation in nitrogen concentration $\left(N_{\text {mass }}\right.$, all needle age-classes pooled) with depth in the canopy was detected ( $N_{\text {mass }}$ vs. $L, r=0.25, p=0.17$; Fig. 3 ). The maximum value of LMA (all needle age-classes pooled) was 1.6 times higher than the minimum observed, and LMA decreased as a function of $L(r=0.76, p<0.001)$. Thus, the nitrogen content $\left(N_{\text {area }}\right)$ increased with increasing available PAR.

\section{Variation in LMA and photosynthetic light response curves}

The values (in zones I-II) of LMA for the 1-year-old needles (all measurement periods pooled) were 88.5 \pm 3.1 $($ mean $\pm \mathrm{SE}), 80.6 \pm 2.3$, and $68.5 \pm 2.4 \mathrm{~g} \cdot \mathrm{m}^{-2}$, with corresponding $N_{\text {mass }}$ values of $1.08 \pm 0.020,1.09 \pm 0.025$, and $1.13 \pm 0.024 \%$. The among-zone differences in the mean LMA were statistically significant $(p<0.05)$ within each data set and overall. No seasonal differences could be detected. The shoot silhouette to total needle surface area ratio (STAR), estimated from the direction of illumination ( $n=$ 35 ), was $0.134 \pm 0.0068$ in zone I, $0.154 \pm 0.0087$ in zone II, and $0.155 \pm 0.0079$ in zone III. It should be noted that these estimates are for "manipulated" shoots.

Considerable within-tree variation was present in the photosynthetic light response curves (Fig. 4, tree height $13.3 \mathrm{~m}$, shoots from 9.8 to $12.5 \mathrm{~m}$ ). However, the variation was not systematic with height. Within each of the three trees sampled in June, the area-based $A_{\max }$ varied twofold, ranging from 2.73 to $5.53 \mu \mathrm{mol} \cdot \mathrm{m}^{-2} \cdot \mathrm{s}^{-1}$ in the tree shown in Fig. 4A. The overall range in the estimates of the area-based $A_{\max }$ was $3.97-8.93 \mu \mathrm{mol} \cdot \mathrm{m}^{-2} \cdot \mathrm{s}^{-1}$ in July and 2.84 $8.61 \mu \mathrm{mol} \cdot \mathrm{m}^{-2} \cdot \mathrm{s}^{-1}$ in August. The lower $\mathrm{CO}_{2}$-exchange rates and higher dark respiration rates in June, as compared with those observed in July or August, could be explained by an abnormally cool period prior to the measurements, which probably had influenced the spring recovery of photosynthesis.

Mean values and standard errors of the $\mathrm{CO}_{2}$-exchange characteristics for each canopy zone are shown in Table 1. No statistically significant differences were found in mean $\alpha$ values, describing the rate of photosynthesis per unit of available carbon at saturating values of PAR. In July and August data, the values of a decreased slightly with canopy depth, but these trends disappeared when the rates were expressed on a dry-mass basis. The variation in the estimate of $q$ was small, with mean overall being somewhat smaller in June than in July.

The values of $A_{\max }$ reflect the combination of the values for $\alpha$ and $g_{\mathrm{s}}$. The relative differences in mean values of $A_{\max }$ corresponded to those observed in the values of $\alpha$, yet again, 
Fig. 2. (A) Daily PAR irradiance $\left(I_{\text {day }}, \mathrm{mol} \cdot \mathrm{m}^{-2} \cdot \mathrm{day}^{-1}\right)$ on a relatively clear day (July 16, 1997, $24 \mathrm{~h}$ ) as a function of cumulative leaf area $\left(L, \mathrm{~m}^{2} \cdot \mathrm{m}^{-2}\right)$. (B) Frequency distributions of PAR irradiance on the same day, measured at heights of 10.7 (open bars) and $8.3 \mathrm{~m}$ (solid bars).
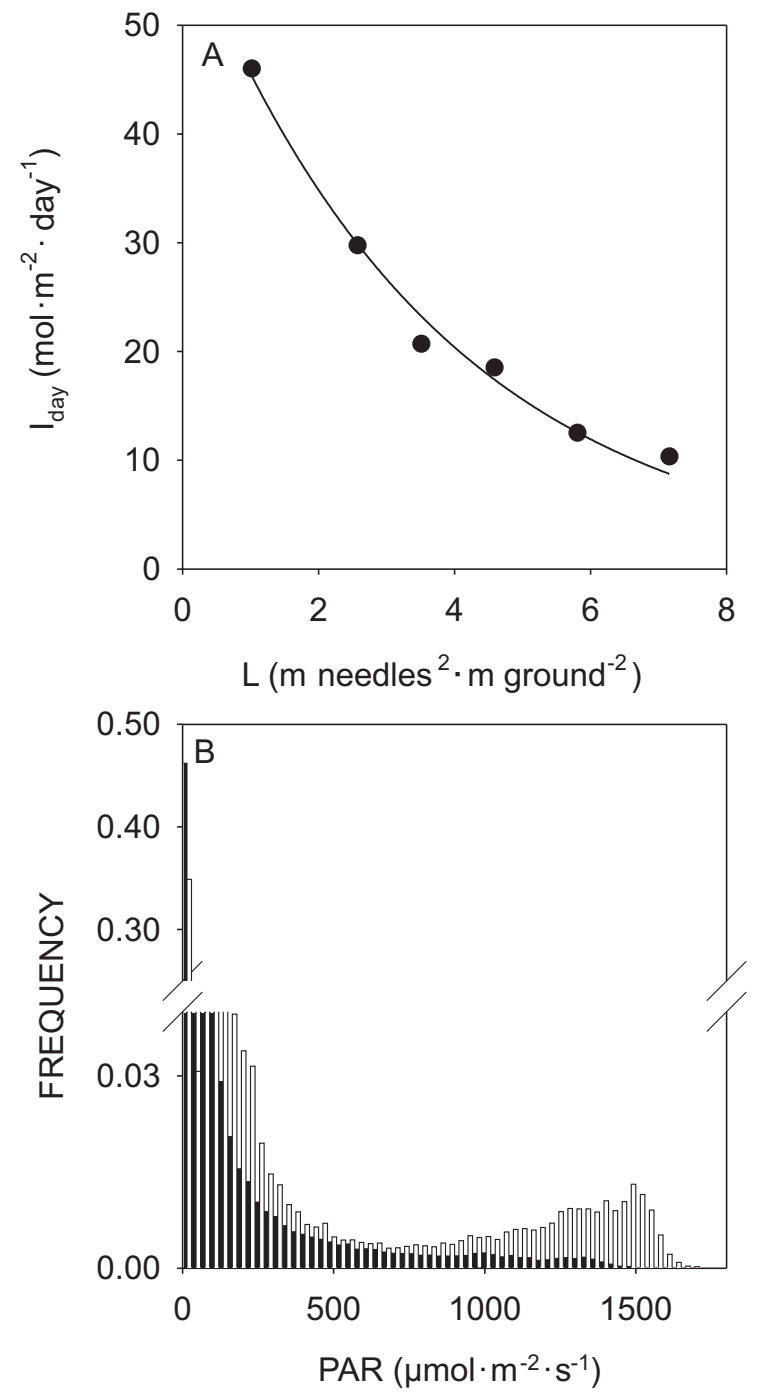

the differences were not statistically significant. A slight decreasing trend with depth, comparable with that in the areabased values of $A_{\max }$, was observed in the mean values of $g_{\mathrm{s}}$ estimated at saturating levels of PAR. The differences in the mean values of $g_{s}$, intercellular $\mathrm{CO}_{2}$ mole fraction, and the estimate of intrinsic water-use efficiency $(\lambda)$ were not statistically significant.

The $R_{\mathrm{d}}$ values decreased with canopy depth. Differences in the area-based values of $R_{\mathrm{d}}$ were statisticlly significant ( $p<0.05)$ within each data set. Mass-based values of $R_{\mathrm{d}}$ also decreased with increasing depth, but these differences were not significant. Although nitrogen content (and LMA) decreased with increasing depth in the canopy, the area-based $A_{\max }$ was only weakly correlated with $N_{\text {area }}(r=0.33, p<$ 0.05 ) or LMA (Fig. 5A; $r=0.40, p<0.05$; July and August data pooled). The values of area-based $R_{\mathrm{d}}$, in turn, showed a closer correlation in all data sets, both with $N_{\text {area }}(0.54, p<$ 0.001 ) and LMA (Fig. 5B; $r=0.74, p<0.001$, data from July and August).
Fig. 3. Leaf mass per area (LMA, $\left.\mathrm{g} \cdot \mathrm{m}^{-2}\right)(\mathbf{O})$ and $N_{\text {mass }}(\%)(\bigcirc)$ as a function of cumulative leaf area $\left(L, \mathrm{~m}^{2} \cdot \mathrm{m}^{-2}\right)$.

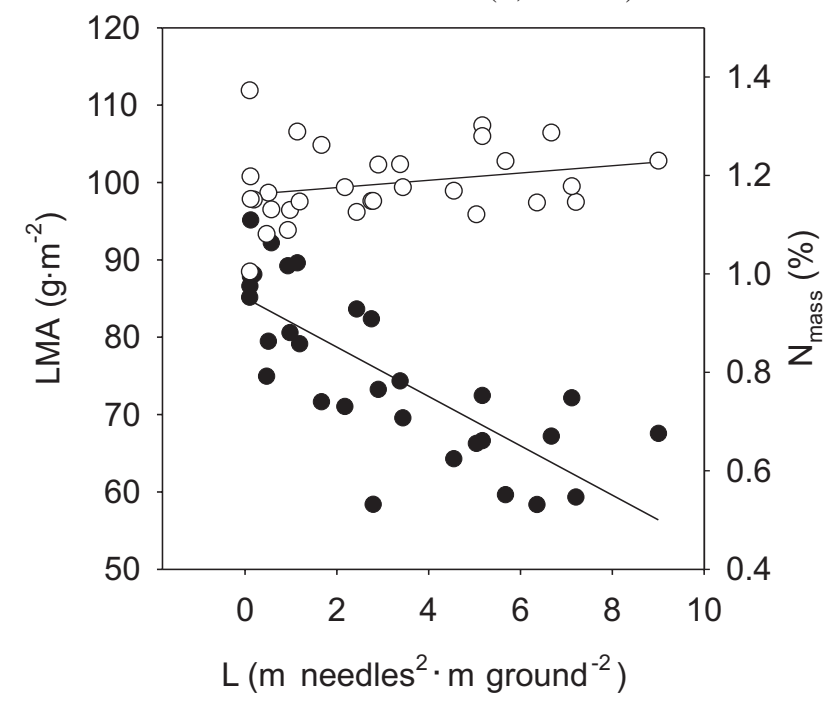

Daily $\mathrm{CO}_{2}$ exchange

The $\mathrm{CO}_{2}$ exchange per unit needle area $\left(A_{\mathrm{c}}\right)$, over the test day (July 16), was first estimated by integrating the mean response curve of a shoot from the zones I, II, and III over the PAR distribution measured at the levels of 10.7, 9.5, and $8.3 \mathrm{~m}$, respectively. In the second calculation, no acclimation was assumed, and the performance of the upper canopy shoot (zone I) was simulated in the light environments of the middle and bottom of the canopy.

Estimates of $A_{\mathrm{c}}$ as a function of daily PAR irradiance $\left(I_{\text {day }}\right)$ are shown in Fig. 6A. When the actual parameter values were used, the estimates of $A_{\mathrm{c}}$ were higher at the two lower levels than in the situation where the response of a "sun shoot" (parameters form zone I) was integrated over the PAR distributions at all the three levels. This was due to differences in dark respiration rate and a concomitant shift in the light compensation point. When the June parameters were used, assuming no acclimation resulted in a negative carbon balance at the bottom of the canopy.

The whole-canopy $\mathrm{CO}_{2}$ exchange was calculated combining the estimates of the $\mathrm{CO}_{2}$ exchange per unit needle area $\left(A_{\mathrm{c}}\right)$ with the amount of needle area in the three canopy zones (Fig. 6B). Assuming no acclimation, i.e., using the shoot response curve from the top of the canopy, estimates of the total canopy $\mathrm{CO}_{2}$ exchange were $79 \%$ (June), $12 \%$ (July), and 13\% (August) lower than those obtained taking into account the observed differences in the parameter values.

\section{Discussion}

Analysing the changes in performance of leaves or shoots along the light gradient within the canopy is essential in developing methods for estimating canopy $\mathrm{CO}_{2}$ exchange. Shade acclimation in conifers involves changes in needle and shoot structure as well as acclimation of the photosynthetic properties. While shade acclimation studies have a long tradition, separation between physiological and structural components has proven to be problematic. Furthermore, structural adjustments, changing the light intercep- 
Fig. 4. $\mathrm{CO}_{2}$ exchange $\left(A_{\mathrm{n}}\right)$ expressed on a total needle area basis $\left(\mu \mathrm{mol} \cdot \mathrm{m}^{-2} \cdot \mathrm{s}^{-1}\right)(\mathrm{A})$ and on a dry-mass basis $\left(\mu \mathrm{mol} \cdot \mathrm{g}^{-1} \cdot \mathrm{s}^{-1}\right)(\mathrm{B})$ as functions of incident PAR irradiance $\left(\mu \mathrm{mol} \cdot \mathrm{m}^{-2} \cdot \mathrm{s}^{-1}\right)$ of seven shoots from the same tree. Heights of branches: $12.5 \mathrm{~m}(\mathrm{O})$, $12.0 \mathrm{~m}(\triangle), 11.6 \mathrm{~m}(\diamond), 11.1 \mathrm{~m}(\nabla), 10.7 \mathrm{~m}(\bullet), 10.3 \mathrm{~m}(\mathbf{\Delta})$, and $9.8 \mathrm{~m}(\diamond)$. A photograph of shoot silhouette is shown in Fig. 4A, where the view angle corresponds to the direction of the light beam.

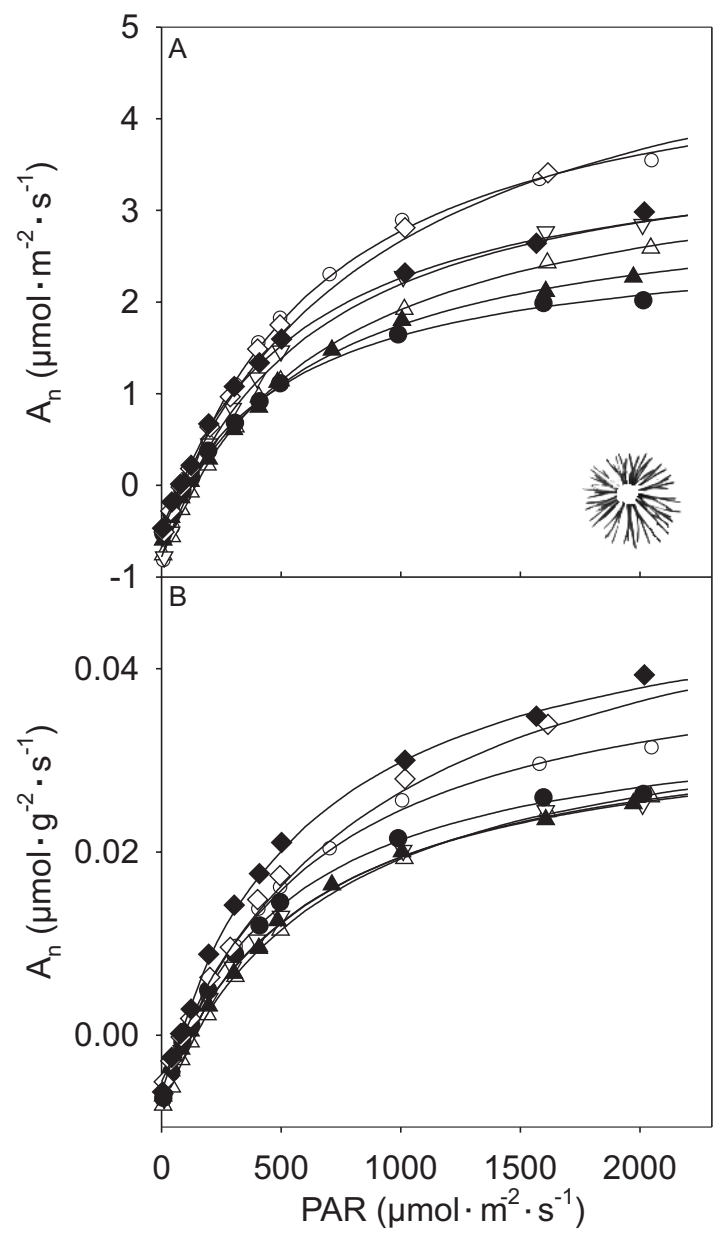

tion of individual needles and shoots, simultaneously alter the availability of light deeper in the canopy. The inclusion of realistic distributions of PAR into canopy models is still relatively uncommon, but theoretical work (e.g., Stenberg 1998 ) indicates that it is important for obtaining realistic estimates of canopy photosynthesis.

In the present work we investigated the differences in photosynthetic light response curves along the vertical light gradient within a Scots pine canopy. The role of shade acclimation on $\mathrm{CO}_{2}$ exchange of Scots pine shoots was evaluated by integrating the photosynthetic light response curves of shoots over the daily distributions of PAR irradiance measured at specific depths within the canopy. For this we sampled shoots from different heights in the canopy. Height is a practical, yet not the most efficient, sampling criterion regarding the light environment, which in a grouped pine stand is characterized by considerable penetration of direct radiation to the lower levels in the canopy. Nevertheless, our sampling covered most of the spatial variation in the properties of the 1-year-old needles, excluding the extremes, i.e., the most exposed and the most shaded ones.

While a "semicontrolled" experiment (e.g., excised twigs, artificial light source) is often the only possible method for measuring photosynthetic light responses, the ecological meaningfulness of this type of experiments is debatable (see Grace et al. 1997). One can argue that the gas-exchange behavior of excised shoots may differ from the performance of intact shoots under actual crown exposure conditions. However, the excision itself does not seem to have any effect on photosynthetic rates of Scots pine shoots (Beadle et al. 1985), and gas-exchange rates measured in similar conditions are comparable and are likely to reflect the potential gas-exchange rates of shoots in the prevailing conditions. However, another important aspect to be considered is the three-dimensional structure of needles and shoots. Shoot structure, involving mutual shading and different inclinations of needles, causes variation in the irradiance on the needle surfaces. The photosynthetic rate of shoot (or a single needle) represents the sum of processes in the individual needle area elements (see Stenberg et al. 1995); PAR received by each of them cannot be directly measured.

We "fixed" the shoot structure so that its effect on the photosynthetic light response curve would be similar in all the shoots, and therefore, the observed variation reflected physiological differences. The differences in shoot silhouette to total needle area ratio (STAR) indicated that this standardization failed to be completely achieved, likely causing some of the unexplained variation in the response curves. For estimating daily carbon balance, $\mathrm{CO}_{2}$ exchange was calculated for "average" shoots (representing the three canopy zones) placed at different depths in the canopy over an example day in the middle of the summer. In clear-sky conditions the vertical light gradient within the canopy is steep, and changes in the shape of irradiance distributions are pronounced. In conjunction with the gas-exchange measurements conducted in the laboratory, daily $\mathrm{CO}_{2}$ exchange was calculated for shoots as a function of available (incoming) PAR irradiance on a horizontal surface. This implies that the canopy was assumed to be horizontally homogenous and to consist of shoots having identical structure and orientation (i.e., identical light interception efficiency). Integration of the photosynthetic light response curves and the PAR irradiance distributions give information on the combined effect of changes in the photosynthetic parameters and the spatial and temporal variation in PAR on $\mathrm{CO}_{2}$ exchange. Given these background assumptions, the canopy-level $\mathrm{CO}_{2}$-exchange estimates (in absolute terms) should be interpreted with caution, whereas the relative differences in the estimates between shoots and zones can be evaluated

\section{Acclimation of needle structure and $\mathrm{CO}_{2}$ exchange properties along the light gradient}

The observed decrease in LMA with decreasing available light in the canopy is in general agreement with the earlier findings in coniferous canopies (Kull and Koppel 1987; Niinemets and Kull 1995; Dang et al. 1997; Bond et al. 1999). Foliar $N_{\text {mass }}$ did not vary with depth in the canopy, whereas $N_{\text {area }}$ increased towards the top because of differences in the values of LMA. The vertical range in the values of LMA was, however, smaller than previously reported for 
Table 1. Carboxylation efficiency $(\alpha)$, quantum yield $(q)$, maximum $\mathrm{CO}_{2}$ exchange rate $\left(A_{\max }\right)$, dark respiration rate $\left(R_{\mathrm{d}}\right)$, and stomatal conductance $\left(g_{\mathrm{s}}\right)$ measured in June, July, and August.

\begin{tabular}{|c|c|c|c|c|c|c|c|}
\hline $\begin{array}{l}\text { Month and } \\
\text { canopy zone }\end{array}$ & $\begin{array}{l}\alpha \\
\left(\mathrm{mmol} \cdot \mathrm{m}^{-2} \cdot \mathrm{s}^{-1}\right)\end{array}$ & $q$ & $\begin{array}{l}A_{\max }, \text { area } \\
\left(\mu \mathrm{mol} \cdot \mathrm{m}^{-2} \cdot \mathrm{s}^{-1}\right)\end{array}$ & $\begin{array}{l}A_{\max }, \operatorname{mass} \\
\left(\mathrm{nmol} \cdot \mathrm{g}^{-1} \cdot \mathrm{s}^{-1}\right)\end{array}$ & $\begin{array}{l}R_{\mathrm{d}}, \text { area } \\
\left(\mu \mathrm{mol} \cdot \mathrm{m}^{-2} \cdot \mathrm{s}^{-1}\right)\end{array}$ & $\begin{array}{l}R_{\mathrm{d}}, \text { mass } \\
\left(\mathrm{nmol} \cdot \mathrm{g}^{-1} \cdot \mathrm{s}^{-1}\right)\end{array}$ & $\begin{array}{l}g_{\mathrm{s}} \\
\left(\mathrm{mol} \cdot \mathrm{m}^{-2} \cdot \mathrm{s}^{-1}\right)\end{array}$ \\
\hline \multicolumn{8}{|l|}{ June } \\
\hline I & $18.2(1.90)$ & $0.042(0.0029)$ & $4.18(0.51)$ & $41.5(5.80)$ & $0.69(0.058)$ & $6.62(0.39)$ & $0.022(0.0026)$ \\
\hline III & $18.6(0.87)$ & $0.047(0.0050)$ & $4.32(0.23)$ & $59.4(2.88)$ & $0.44(0.046)$ & $6.11(0.22)$ & $0.023(0.0022)$ \\
\hline \multicolumn{8}{|l|}{ July } \\
\hline III & $23.2(1.72)$ & $0.056(0.0014)$ & $6.00(0.46)$ & $82.6(4.22)$ & $0.23(0.033)$ & $3.54(0.31)$ & $0.030(0.0031)$ \\
\hline \multicolumn{8}{|l|}{ August } \\
\hline I & $22.2(1.46)$ & & $5.76(0.41)$ & $62.9(4.91)$ & $0.42(0.033)$ & $4.38(0.22)$ & $0.035(0.0019)$ \\
\hline II & $20.7(1.37)$ & & $5.26(0.37)$ & $67.7(4.84)$ & $0.28(0.013)$ & $3.47(0.21)$ & $0.029(0.0020)$ \\
\hline III & $19.6(0.48)$ & & $5.05(0.13)$ & $77.5(6.20)$ & $0.22(0.017)$ & $3.54(0.31)$ & $0.028(0.0019)$ \\
\hline
\end{tabular}

Note: Values are means with SEs given in parentheses. $A_{\max }$ and $R_{\mathrm{d}}$ are expressed both on a total needle area and on a dry-mass basis. Only the differences in area-based values of $R_{\mathrm{d}}$ were statistically significant. The values of $q$ are based on a subsamples of shoots measured in June $(n=15)$ and July $(n=20)$.

more shade-tolerant conifers but also for Scots pine (Kellomäki and Oker-Blom 1981; van Hees and Bartelink 1993; Stenberg et al. 2001). By producing leaves with lower construction costs in the bottom of the canopy, productive leaf area could be maintained in lower light (Givnish 1988). Shade-tolerant species have been suggested to have a higher capacity to develop greater leaf area per unit dry mass by decreasing the leaf thickness and a lowering stomatal density (Chen et al. 1996; Sprugel et al. 1996). In support to the hypothesis of a greater shade acclimation potential of shadetolerant versus shade-intolerant species, Bond et al. (1999) found that a shade-intolerant pine (Pinus ponderosa Dougl. ex P. \& C. Laws.) did not grow new needles in low-light conditions, where the more tolerant species still had new growth.

Mean values of area-based $A_{\max }$ increased slightly with height in the canopy. Generally, the differences in photosynthetic parameters between canopy zones were small and variation (especially in $A_{\max }$ ) within each zone was rather large. Our results are similar to those published by Porté and Loustau (1999), who found no statistically significant effect of height in the crown on any of the photosynthetic properties studied within a canopy of Pinus pinaster Ait. In our data, however, the decreasing trend in the area-based dark respiration rate with depth in the canopy was distinct, whereas the differences in the mass-based rate were not statistically significant. The number of studies, which specifically assess the variation in foliar respiration rates within canopies is rather limited. Brooks et al. (1991) reported that needle respiration per unit mass or area decreased with depth in the canopy of Abies amabilis (Dougl.) Forbes, in addition to varying with needle age and season. They concluded that the overall energy needs of foliage decreases sharply as it is overtopped in the canopy.

While correlations between the area-based values of $A_{\max }$ and $N_{\text {area }}$ as well as $A_{\max }$ and LMA were weak, the areabased values of $R_{\mathrm{d}}$ showed a stronger correlation with both $N_{\text {area }}$ and LMA (see Fig. 5). Controversial evidence exists on the relationship between needle $\mathrm{N}$ and photosynthetic capacity in Scots pine (Smolander and Oker-Blom 1989; Vapaavuori
Fig. 5. (A) Maximum $\mathrm{CO}_{2}$ exchange rate $\left(A_{\max }, \mu \mathrm{mol} \cdot \mathrm{m}^{-2} \cdot \mathrm{s}^{-1}\right)$ and (B) dark respiration rate $\left(R_{\mathrm{d}}, \mu \mathrm{mol} \cdot \mathrm{m}^{-2} \cdot \mathrm{s}^{-1}\right)$ as functions of the leaf mass per area (LMA, $\mathrm{g} \cdot \mathrm{m}^{-2}$ ) in June $(\bigcirc)$ and August $(\bigcirc)$.

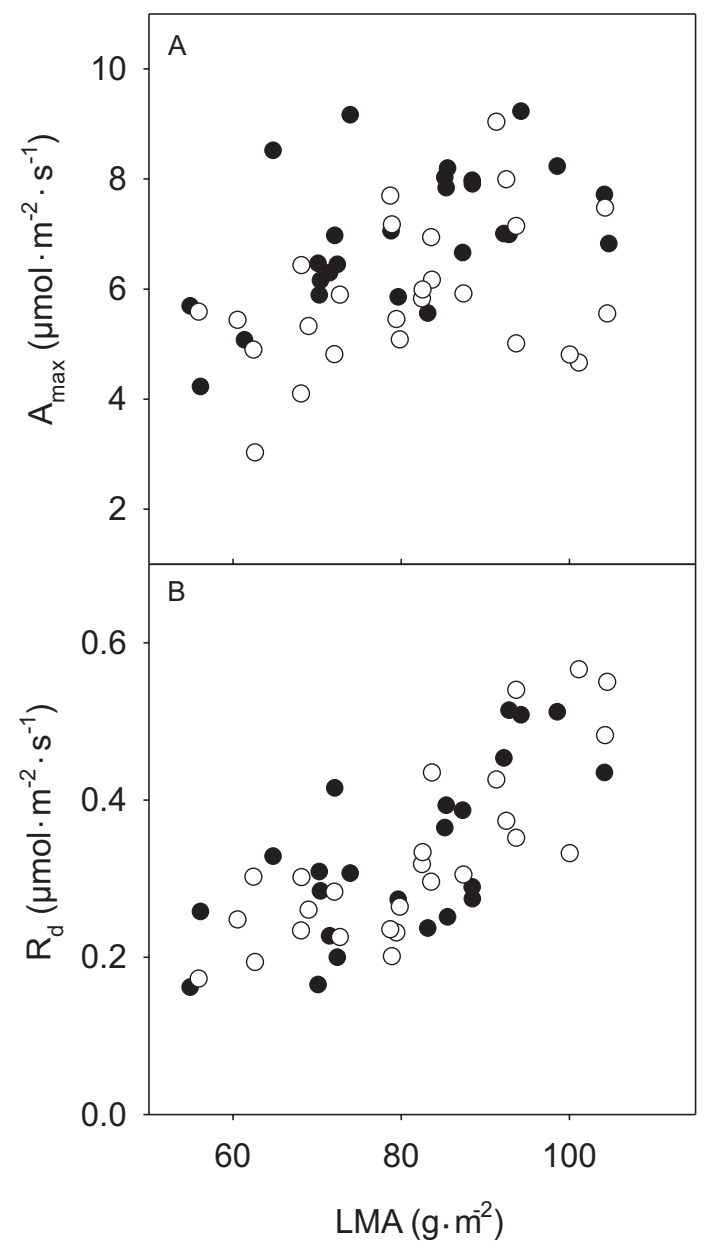

et al. 1995; Kellomäki and Wang 1997) and other conifers (Dang et al. 1997; Bond et al. 1999; Porté and Lousteau 1999; Schoettle and Smith 1999). This controversy can be 
Fig. 6. (A) $\mathrm{CO}_{2}$ exchange $\left(\mathrm{mol} \cdot \mathrm{m}^{-2} \cdot \mathrm{day}^{-1}\right)$ on July 16,1997 , at three levels $(10.7,9.5$, and $8.3 \mathrm{~m})$ in the canopy as a function of the daily PAR irradiance $\left(I_{\text {day }}, \mathrm{mol} \cdot \mathrm{m}^{-2} \cdot \mathrm{day}^{-1}\right)$. Solid symbols refer to values calculated using the mean $\mathrm{CO}_{2}$ exchange responses to PAR (from zone I at $10.7 \mathrm{~m}$, zone II at $9.5 \mathrm{~m}$, and zone III at $8.3 \mathrm{~m}$ ), and open symbols are values obtained using the response curve from zone I at the three levels. Parameters from June (circles), July (squares), and August (triangles). (B) $\mathrm{CO}_{2}$ exchange $\left(\mu \mathrm{mol} \cdot \mathrm{m}\right.$ ground $\left.^{-2} \cdot \mathrm{day}^{-1}\right)$ of the canopy on July 16,1997 , calculated using the $\mathrm{CO}_{2}$ exchange rates (shown in Fig. 6A) and LAI of canopy zones I-III, and using the observed parameter values (solid bars) and assuming no acclimation (open bars).
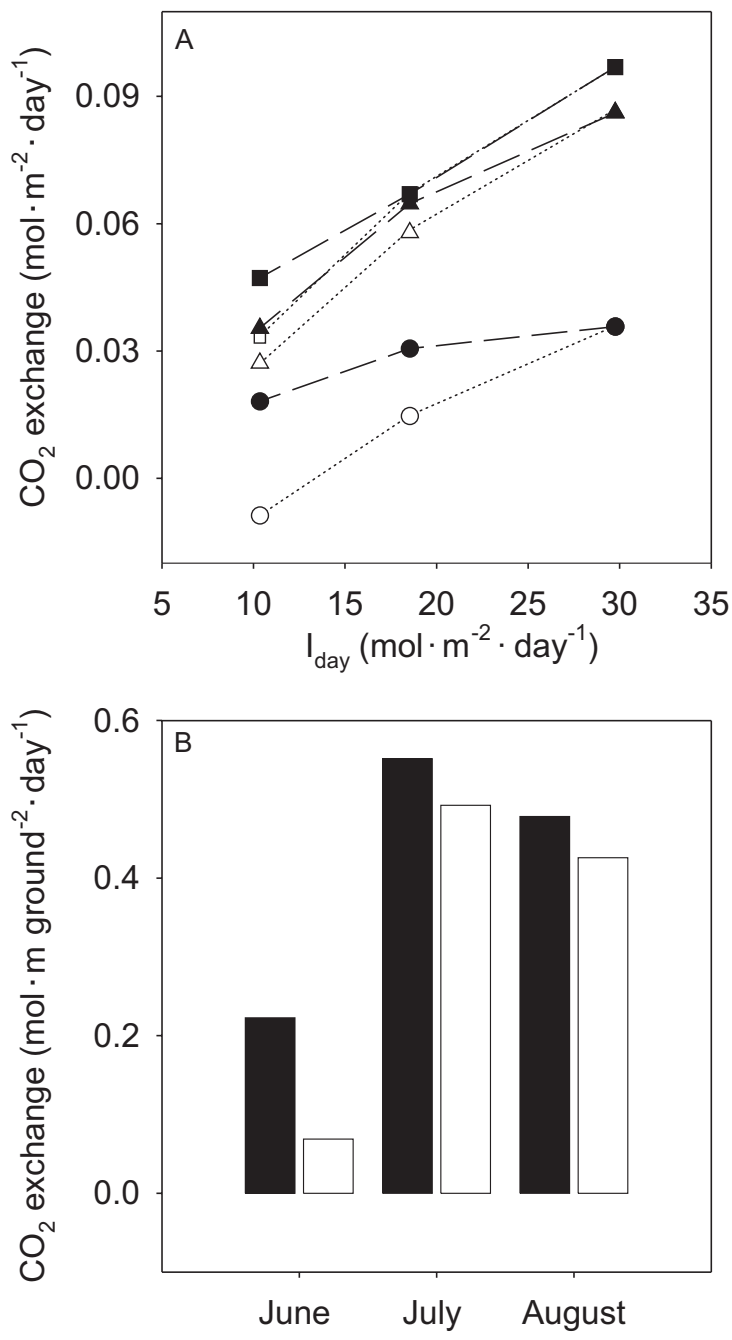

found in the results of analysis that are based on shoot-level as well as needle-level gas-exchange measurements suggesting that needle ultrastructure and the partitioning of $\mathrm{N}$ between functional and structural compounds requires more research. For instance, changes in LMA may result from increased thickness, which is likely to enhance the photosynthetic capacity per unit needle area (increased mesophyll area to total area/volume ratio), or leaf density, which would have the opposite effect on the capacity (Björkman 1981; Niinemets 1999).

\section{$\mathrm{CO}_{2}$ exchange integrated over a day}

Based on our daily estimates of $\mathrm{CO}_{2}$ exchange, an average sun shoot fixed less $\mathrm{CO}_{2}$ per unit needle area than a shade shoot in low light conditions. This was achieved by the lower respiration rate and light compensation point of the latter as compared with the former. However, because the differences in the values of $A_{\max }$ were small, an average shoot from the bottom of the canopy would perform better also in higher levels of available PAR. It raises the question of why leaves are produced that are thicker and have higher respiration rates but are not clearly more efficient. It might simply be that more resistant leaves with a thicker cuticle and cell walls, are needed in the more exposed growing conditions in the upper canopy (Niinemets and Kull 1995).

Our results suggest that acclimation of respiration rate plays an important role in the daily carbon balance. However, to better quantify this one should consider the distributions of PAR irradiance on the needle surface area including the effects of shoot structure and orientation on the light interception efficiency (see Stenberg et al. 2001). For example, if the changes in the shoot structure causing increasing light interception efficiency with shading, as was reported by Stenberg et al. (2001), were included in the present analysis, then the relative differences between daily $\mathrm{CO}_{2}$ exchange of the sun and shade shoots would have been greater.

\section{Conclusions}

In examining the distributions of PAR irradiance, needle mass, foliar N, and photosynthetic properties in a Scots pine canopy, we found structural acclimation of the needles with increased shading. The changes in the biochemical machinery were less clear. A significant decrease in the dark respiration rate did, however, occur with increasing depth in the canopy. Comparison of the estimates of daily $\mathrm{CO}_{2}$ exchange suggested that the apparently small differences in the mean response curves were reflected as enhanced performance of the shade shoots in low light conditions.

\section{References}

Beadle, C.L., Talbot, H., Neilson, R.E., and Jarvis, P.G. 1985. Stomatal conductance and photosynthesis in a mature Scots pine forest. I. Diurnal and spatial variation in shoots. J. Appl. Ecol. 22: 557-571.

Bergh, J. 1997. Climatic and nutritional constraints to productivity in Norway spruce. Ph.D. thesis, Swedish University of Agricultural Sciences, Umeå. Acta Univ. Agric. Suec. Sivestria 37.

Berninger, F., and Hari, P. 1993. Optimal control of gas exchange: evidence from field data. Ann. Bot. (London), 71: 135-140.

Berninger, F., Mäkelä, A., and Hari, P. 1996. Optimal control of gas exchange during drought: empirical evidence. Ann. Bot. (London), 77: 469-476.

Björkman, O. 1981. Responses to different quantum flux densities. In Encyclopedia of Plant Physiology. New series. Vol. 12A. Edited by O.L. Lange, P.S. Nobel, C.B. Osmond, and H. Zeigler. Springer-Verlag, Berlin, Heidelberg, New York. pp. 57-107.

Bond, B.J., Farnsworth, B.T., Coulombe, R.A., and Winner, W.E. 1999. Foliage physiology and biochemistry in response to light gradients in conifers with varying shade tolerance. Oecologia, 120: $183-192$.

Brooks, J.R., Hinkcley, T.M., Ford, E.D., and Sprugel, D.G. 1991. Foliage dark respiration in Abies amabilis (Dougl) Forbes: variation within the canopy. Tree Physiol. 9: 325-338.

Chen, H.H.Y., Klinka, K., and Kayahara, G.J. 1996. Effects of light on growth, crown architecture, and specific needle area for natu- 
rally established Pinus contorta var. latifolia and Pseudotsuga menziesii var. glauca saplings. Can. J. For. Res. 26: 1149-1157.

Cowan, I.R. 1977. Stomatal behaviour and the environment. Adv. Bot. Res. 4: 117-227.

Dang, L.D., Margolis, H.A., Sy, M., Coyea, M.R., Collatz, G.J., and Walthall, C.L. 1997. Profiles of photosynthetically active radiation, nitrogen and photosynthetic capacity in the boreal forest: implications for scaling from leaf to canopy. J. Geophys. Res. 102: 28845 - 28859.

Ellsworth, D.S., and Reich, P.B. 1993. Canopy structure and vertical patterns of photosynthesis and related leaf traits in a deciduous forest. Oecologia, 96: 169-178.

Givnish, T.J. 1988. Adaptation to sun and shade: a whole plant perspective. Aust. J. Plant Physiol. 15: 63-92.

Grace, J., van Gardeningen, P.R., and Luan, J. 1997. Tackling large scale problems by scaling-up. In Scaling up from cell to landscape. Edited by P.R. van Gardingen, G.M. Foody, and P.J. Curran. Cambridge University Press, Cambridge, U.K. pp. 7-16.

Hari, P., Mäkelä, A., Korpilahti, E., and Holmberg, M. 1986. Optimal control of gas exchange. Tree Physiol. 2: 169-175.

Hari, P., Mäkelä, A., Berninger, F., and Pohja, T. 1999. Field evidence for the optimality hypothesis of gas exchange in plants. Aust. J. Plant Physiol. 26: 239-244.

Hari, P., Mäkelä, A., and Pohja, T. 2000. Surprising implications of the optimality hypothesis of stomatal regulation gain support in a field test. Aust. J. Plant Physiol. 27: 77-80.

Harley, P.C., and Baldocchi, D.D. 1995. Scaling carbon dioxide and water vapour exchange from leaf to canopy in a deciduous forest. 1. Leaf model parametrization. Plant Cell Environ. 18: 1146-1156.

Irvine, J., Perks, M.P., Magnani, F., and Grace, J. 1998. The response of Pinus sylvestris to drought: stomatal control of transpiration and hydraulic conductance. Tree Physiol. 18: 393-402.

Kaipiainen, L., and Hari, P. 1985. Consistencies in the structure of Scots pine. In Crop physiology of forest trees. Edited by P.M.A. Tigersted, P. Puttonen, and V. Koski. Helsinki University Press, Helsinki, Finland. pp. 32-37.

Kellomäki, S., and Oker-Blom, P. 1981. Specific needle area of Scots pine and its dependence on light conditions inside the canopy. Silva Fenn. 15: 190-198.

Kellomäki, S., and Wang, K.Y. 1997. Effects of long-term $\mathrm{CO}_{2}$ and temperature elevation on crown nitrogen disribution and daily photosynthetic performance of Scots pine. For. Ecol. Manage. 99: 309-326.

Korpilahti, E., and Hari, P. 1978. A method for approximating the effect of shading on the total amount of $\mathrm{CO}_{2}$ fixed by branches of different species during the growing season. Flora, 167: 257-264.

Koskela, J., Hari, P., and Pipatwattanakul, D. 1999. Analysis of gas exchange of Merkus pine populations by the optimality approach. Tree Physiol. 19: 511-518.

Kull, O., and Koppel, A. 1987. Net photosynthetic response of shoots from different crown positions and age in Picea abies (L.) Karst. Scand. J. For. Res. 2: 157-166.

Kull, O., and Niinemets, Ü. 1998. Distributions of leaf photosynthetic properties in tree canopies: comparison of species with different shade tolerance. Funct. Ecol. 12: 472-479.

Leverenz, J.W. 1996. Shade-shoot structure, photosynthetic performance in the field, and photosynthetic capacity of evergreen conifers. Tree Physiol. 16: 109-114.

Mäkelä, A., Berninger, F., and Hari, P. 1996. Optimal control of gas exchange during drought: theoretical analysis. Ann. Bot. (London), 77: 461-467.

Niinemets, Ü. 1999. Research review. Components of leaf dry mass per area—thickness and density—alter leaf photosynthetic capacity in reverse directions in woody plants. New Phytol. 144: $35-47$.

Niinemets, Ü., and Kull, O. 1995. Effects of light availability and tree size on the architecture of assimilative surface in the canopy of Picea abies: variation in needle morphology. Tree Physiol. 15: $307-315$.

Niinemets, Ü., and Tenhunen, J.D. 1997. A model separating leaf structural and physiological effects on carbon gain along light gradients for the shade-tolerant species Acer saccharum. Plant Cell Environ. 20: 845-866.

Oker-Blom, P., and Smolander, H. 1988. The ratio of shoot silhouette area to total needle area in Scots pine. For. Sci. 34: 894-906.

Palmroth, S., Berninger, F., Nikinmaa, E., Lloyd, J., Pulkkinen, P., and Hari, P. 1999. No water conservation behaviour but structural adaptation was observed in Scots pine from wet to dry climates. Oecologia, 121: 302-309.

Palva, L., Garam. E., Manoocherhri, F., Sepponen, R., Hari, P., Rajala K, Ruotoistenmäki, H., and Seppälä, I. 1998. A novel multipoint measuring system of photosynthetically active radiation. Agric. For. Meteorol. 89: 141-147.

Porté, A., and Loustau, D. 1999. Variability of the photosynthetic characteristic of mature needles within the crown of a 25-yearold Pinus pinaster. Tree Physiol. 18: 223-232.

Reich, P.B., Walters, M.B., and Ellsworth, D.S. 1991. Leaf age and season influence the relationships between leaf nitrogen, leaf mass per area and photosynthesis in maple and oak trees. Plant Cell Environ. 14: 251-259.

Schoettle, A.W., and Smith, W.K. 1999. Interrelationships among light photosynthesis and nitrogen in the crown of mature Pinus contorta ssp. latifolia. Tree Physiol. 19: 13-22.

Smolander, H., and Oker-Blom, P. 1989. The effect of nitrogen content on the photosynthesis of Scots pine needles and shoots. Ann. Sci. For. 46: 473-475.

Sprugel, D.G., Brooks, J.R., and Hinckley, T.M. 1996. Effect of light on shoot and needle morphology in Abies amabilis. Tree Physiol. 16: 91-98.

Stenberg, P. 1998. Implications of shoot structure on the rate of photosynthesis at different levels in a coniferous canopy using a model incorporating grouping and penumbra. Funct. Ecol. 12: 82-91.

Stenberg, P., DeLucia, E.H., Schoettle, A.W., and Smolander, H. 1995. Photosynthetic light capture and processing from cell to canopy. In Resource Physiology of Conifers. Edited by W.K. Smith and T.M. Hinkley. Physiological Ecology Series. Academic Press, London. pp. 3-38.

Stenberg, P., Kangas, T., Smolander, H., and Linder, S. 1999. Shoot structure, canopy openness, and light interception in Norway spruce. Plant Cell Environ. 22: 1133-1142.

Stenberg, P., Palmroth, S., Bond, B.J., Sprugel, D.G., and Smolander, H. 2001. Shoot structure and photosynthetic efficiency along the light gradient in Scots pine canopy. Tree Physiol. 21. In press.

van Hees, A.F.M., and Bartelink, H.H. 1993. Needle area relationships of Scots pine in the Netherlands. For. Ecol. Manage. 58: 19-31.

Vapaavuori, E.M., Vuorinen, A.J., Aphalo, P.J., and Smolander, H. 1995. Relationship between net photosynthesis and nitrogen in Scots pine: seasonal variation in seedlings and shoots. Plant Soil, 168-169: 263-270.

Vesala, T., Markkanen, T., Palva, L., Siivola, E., Palmroth, S., and Hari, P. 2000. Effect of variations of PAR on $\mathrm{CO}_{2}$ exchange estimation for Scots pine. Agric. For. Meteorol. 100: 337-347. 